\title{
Socio-legal representation of freedom of conscience
}

\author{
Vitalii Novikov*, Vlastimil Vicen ${ }^{* *}$, Yurii Semchuk**
}

Received: 2021-09-05

Accepted: 2021-10-22

DOI: bttp:/ / doi.org/10.46489/lbsh.2021-1-3-2

\begin{abstract}
Freedom of conscience is the crucial goal we need to achieve for a sustainable future. The article examines the problems of freedom of conscience in various spheres of public relations. We have considered multiple aspects of this phenomenon: legal, economic, ethical, philosophical, epistemological, social. We paid special attention to the legal aspect of freedom of conscience. Due to this, we analyzed the existing legal guarantees of believers, non-believers and atheists, to determine the prospects for their further development. We have drawn attention to the fact that reducing the problems of freedom of conscience only to the legal aspect leads to the substitution of the worldview principles of a democratic society and to ideologizing. We have analyzed the different views of scholars on freedom of conscience as ethical, moral and personal categories. Based on a comprehensive sociolegal analysis of freedom of conscience, we concluded that the most important aspects of freedom of conscience are social, philosophical and legal. Finally, we argue that freedom of conscience is the basis for sustainable development in meaning of the 10th and 16th SDGs.
\end{abstract}

Keywords: freedom of conscience, legal aspect, legal consciousness, economic aspect, morality, ethical aspect, religion, philosophical category, epistemological aspect, social aspect.

\footnotetext{
* Vitalii Novikov, Candidate of Juridical Sciences, Associate Professor, Dean of the Juridical Faculty, Lviv university of business and law, Kulparkivska st., 99, 79021 Lviv, Ukraine, e-mail: vnovikov@gmail.com, ORCID: https://orcid.org/0000-0003-0935-4000

** Vlastimil Vicen, Dr.h.c., JUDr., Ing., PhD., Vice-Rector for Security and Defense, College of Economics and Management in Public Administration, Furdekova st., 3240/16, 85104 Bratislava, Slovakia, e-mail: vlastimil.vicen@vsemvs.sk, ORCID: https://orcid.org/0000-0002-1336-5549

${ }^{* * *}$ Yurii Semchuk, PhD, Assosiated Professor of the Department of Judiciary, Prosecution and Advocacy, Lviv University of Business and Law, 99 Kulparkivska Str., Lviv, 79021, Ukraine, ORCID: https://orcid.org/0000-0002-2829-0834
} 


\section{INTRODUCTION}

The modern Ukrainian state sought to overcome the contradictions between legislation and the practical solution of problems of freedom of conscience (Mykhaleyko, 2020). However, relevant changes are a condition for building inclusive civil society institutions and ensuring sustainable development in global processes.

Real provision of freedom of conscience is possible only if changes in society's economic, political, spiritual, organizational spheres are taken into account (Donnikova, 2020). The level of genuine freedom of conscience is determined by historical, social, legal, and political aspects. Improving the scientific and methodological basis of freedom of conscience and the practice of its application is a necessary condition for the harmonious development of Ukrainian society (Kolodnyi, 2005). Clarifying the related issues will be an effective solution to the existing problems in state-confessional relations. A theoretical and methodological study of the problems of freedom of conscience is possible only when this concept's general specifics and essence are taken into account.

The effectiveness of socio-legal analysis of freedom of conscience is improved by observing the relationship of various aspects of this problem. Considering the freedom of conscience in various spheres of public relations, we can identify aspects of this phenomenon. According to modern researchers, legal, economic, and moral are the most significant of them (Brazhnyk, 1999). To these aspects of freedom of conscience can be added and philosophical in which freedom of conscience is considered in connection with the problem of conscience in general and general sociological, which takes into account the relationship between the problem of freedom and freedom of conscience. In addition, there is a psychological, religious and epistemological aspect of the study of the concept of freedom of conscience, directly related to worldviews and socio-political grounds (Mariten, 2002).

Both classics of socio-philosophical thought and jurists have devoted their works to studying various aspects of freedom of conscience.
However, despite the widespread interest in the problems of freedom of conscience, modern literature has not paid due attention to a comprehensive socio-legal analysis of freedom of conscience. The analysis of the legal guarantees of believers and non-believers with a view to their further development requires more detailed attention.

The purpose of the study is to generalize and specify the socio-legal ideas about freedom of conscience and the formation of a generalized rationale for its problems.

\section{RESULTS}

The legal aspect of freedom of conscience is one of the most developed in the literature. The attitude of researchers to it at different stages of the historical development of society was different (Rozenbaum, 1985). Underestimation of this aspect is often one of the reasons for erroneous actions in implementing state and church policy. In the USSR, under a totalitarian regime, it was proposed to consider freedom of conscience only as a personal right of Soviet citizens. It was emphasized that freedom of conscience is individual, which differs from their other rights and freedoms (Ageshin, 1978).

Such allegations created a false notion that freedom of conscience should be viewed independently of other democratic rights and freedoms. At the same time, freedom of conscience is one of the most important constitutional human rights and is determined by the level of development of democracy. In the late '70s and early '80s of the last century, the idea was expressed about the priority of the legal aspect of freedom of conscience, which led to the ideologization of existing law. As a result, law was intertwined with politics and ideological theory, actively acted as an ideological factor in shaping people's worldview (Pismanik, 1984).

This kind of opinion gave rise to certain recommendations. Their essence was to raise the level of worldview to atheistic by a deep explanation of legal knowledge in society. In this case, an effective means of moral and ideological education was considered the people's court, court proceedings against believers and religious associations (Kimelev, 1998). Unfortunately, such ideas were already in conflict with the principles of freedom of 
conscience and Soviet legislation on religious cults. This discredited the important democratic right of the people to freedom of conscience.

Theoretical errors in the interpretation of the legal aspect of freedom of conscience in practice turned into gross violations of the principles of democracy. In a true democracy, there should be no practise of dividing people on religious, national or racial grounds (Article 24 of the Constitution of Ukraine). Reducing the problems of freedom of conscience only to the legal aspect led to an artificial narrowing of the scope of this concept, to the substitution of worldview principles of democracy, to ideologizing. This, in turn, contradicts the principles and values of sustainable development.

On the other hand, the analysis of this aspect of freedom of conscience allows us to conclude that it is appropriate to distinguish such a relatively independent form of social consciousness as legal consciousness. It is a set of views and ideas expressing attitudes to law, legality, and what is legitimate or illegal. Legal consciousness is based on legal ideology, which reflects certain social and ideological positions. Legal analysis of freedom of conscience, taking into account the essence and specifics of the concept, allows us to analyze the existing legal guarantees of believers, non-believers and atheists, as well as prospects for their further development.

However, these provisions are not always taken into account. In their research, scholars analyzed the legal peculiarities of freedom of conscience. They suggested that freedom of worship and freedom of atheistic propaganda should be taken outside the scope of freedom of conscience, freedom of speech and freedom of the press (Shahov, 2008).

In our opinion, the point of view of $\mathrm{J}$. Rosenbaum deserves attention, that from legal positions, freedom of conscience "means the right of citizens allowed and guaranteed by the laws of the state freely and independently to define the relation to religion, to carry out the actions proceeding from this relation, provided observance of legality and law and order established in the country" (Ageshin, 1978).

Understanding the legal aspect of freedom of conscience allows developing an effective mechanism of the legal protection of believers of different denominations, as well as nonbelievers and atheists, their right to freedom of choice, equal understanding of laws and legal responsibility for their observance. It should be recognized that in modern conditions, the legal aspect is freedom of conscience as an integral part of human rights. In modern society, there are complex integration processes of market relations, the formation of a single economic structure of society, increasing the level of interdependence of market participants from each other.

This contributes to the achievement of mutual understanding and tolerance between people, regardless of their worldviews. The economic aspect of freedom of conscience stands out in the socio-philosophical analysis of the interaction of political and legal doctrines in forming ideas about freedom of conscience and the relationship of ideas about freedom of conscience with economic development. The determining factor in the formation and development of economic relations is people's purposeful activity to create consumer values, both material and spiritual. At the same time, the influence of the economic structure of society at different levels of its development is manifested indirectly, more often through the sphere of politics and law.

Mistakes and miscalculations made in economic policy distort the scope of democratic rights and freedoms. In this case, objective, economic laws that do not depend on people and create the appropriate logic of events come into force. For example, no matter how progressive the legal principles of freedom of conscience in a combination of commandadministrative and economic structures, their practical provision faces many difficulties, primarily due to the spread of command-andcontrol methods in this area of democratic rights and freedoms (Farber, 1974).

In a regulated market economy, the role and importance of the economic aspect of freedom of conscience will increase. Economic and financial activities of religious and atheistic organizations in the development of civil society require the development of a mechanism for the sufficiency of material guarantees of freedom of conscience. This is, directly and indirectly, important for achieving the goals of sustainable development. 
It should be noted that religious organizations allocate significant funds to the Peace Fund to reconstruct and restore religious buildings, many of which are historical and architectural monuments. The funds allocated for these purposes pursue universal goals. They are addressed to meet the interests of all citizens, regardless of their attitude to religion. Such charitable activity leads to the fact that part of the funds of religious organizations is returned to the state and society.

Obviously, with the formation of relations in modern civil society in Ukraine, the importance of personal position and human responsibility to society for their actions and deeds increases. In this regard, it draws special attention to the processes of transition of the individual from legal consciousness to moral consciousness (Vélez, 2009). The process of strengthening public interest in the moral problems of freedom of conscience is developing. This leads to the selection and theoretical study of the moral aspect of this phenomenon.

In contrast to the philosophical, the moral aspect of freedom of conscience (Fylypovych, 2000) allows us to explore the mechanism of formation of moral conviction of the individual in the correctness of worldview choices between religious denominations or between religious and materialist worldviews, moral justification of actions and deeds.

True freedom of conscience lies not simply in a person's ability to act according to his morals, with his ideas of good and evil, but in the ability to comprehend scientifically sound true criteria of morality, in the ability to organize his life according to these criteria. In this sense, freedom of conscience acts as a socio-legal concept as opposed to the ethical concepts of "freedom" and "conscience" (Ahdar, 2018).

The concept of conscience is defined as awareness of one's own attitude to moral requirements that meet the requirements of society, social class, environment. Conscience acts as a self-assessment of the person of their actions and deeds, based on knowledge of the norms of public morality. Thus, in morality, the process of interaction of norms of public morality and morality of individual, group is constantly carried out. The ideal development of this process is the coincidence of social morality norms with the person's moral beliefs. In fact, the same picture of the interaction of levels of morality is observed in the religious consciousness. In both types of morality, there is the same mechanism of moral regulation.

The study of the moral aspect of freedom of conscience allows us to consider the mechanism of formation of the moral beliefs of the subject in both religious and materialist worldviews (Chavkin, 2018). This mechanism depends on the interaction of objective and subjective factors. The objective side of this process is revealed through the perception of specific historical, social phenomena, relations, processes related to the interests of strata, groups and society as a whole. The subjective factor depends on how each individual is aware of the surrounding reality. Due to this, personal, volitional, emotional qualities have formed a belief in the truth of the decision. Conscience is manifested not only in the form of rational awareness of the moral significance of actions but also in the form of emotional feelings for the correctness of actions in relation to their ideals and evaluation criteria, which focuses on the person. A person's belief that his worldviews are just, true contributes to establishing high moral ideals in life. This is often the starting point for economic, political and legal demands. But a person's beliefs can be both true and false, based on religious and nonreligious beliefs and values. At the same time, it is extremely important to what extent these beliefs contribute to the establishment of universal values in the life of society and the development of progressive tendencies. I. Farber argued that conscience and freedom are primarily ethical categories (Novikov, 1980). The ethical aspect of freedom of conscience implies a person's freedom to be guided by his own desires and views when choosing a worldview, i.e. complete freedom to profess or not to profess any religion (Werth, 2006), to perform or not to perform rites, exercising their civil and political rights (Babie, 2013). In this sense, freedom of conscience is primarily the ability of a person to self-control, to the moral evaluation of their own actions based on an understanding of their responsibility for them (Drobnickij, 1974). 
When considering the ethical aspect of freedom of conscience, the relationship between concepts such as "responsibility" and "citizenship" should be taken into account. Ethicist O. Drobnytsky emphasizes that conscience is a person's ability to adequately assess their actions, beliefs, for the truth of which it is responsible, but in itself is not guaranteed by subjective experiences and selfbelief (Babii, 1994). The problem of responsibility and citizenship acquires special relevance in the study of the relationship "person-society". The humanistic tradition is based on the fact that a person must be civilly responsible for their actions and actions to society, but, conversely, society must consider the interests and needs of the individual and create the necessary conditions to meet personal needs.

Narrowing the range of issues addressed to the problems of freedom of conscience, concretizing the general theory of freedom and responsibility (Fleming, 2018), we can conclude that a democratic society must create the necessary conditions to meet the religious needs of believers, just as for non-believers, atheists. The necessary conditions must be created to meet their intellectual and cultural needs.

Underestimation of the ethical aspect leads to underestimation of the right to an atheistic or religious worldview, to the liberation of conscience from the influence of religion or a person's choice of religious direction (Elguédri, 2017). Being both a philosophical and legal category, freedom of conscience is considered in the unity of these aspects, in their inseparable relationship, interaction and interaction. Such unity determines the basis of the category of freedom of conscience. Since philosophy and law are not identical as different forms of social consciousness, the concepts of philosophical and legal aspects of freedom of conscience are also not identical. The organic combination of the two aspects of the study of the concept of freedom of conscience provides a way to resolve intrapersonal conflict. This contradiction is the need for a person to belong to a particular state and society and the ability to choose one of the known religious systems.

The general sociological aspect of the study of freedom of conscience focuses on worldview problems, helps to identify the links of this concept with such philosophical categories as "freedom", "freedom of will", "responsibility" and others. This approach allows us to show that the concept of "freedom" is a conscious need to act in accordance with their knowledge, ideas and beliefs in choosing a worldview between religious and atheistic worldview. As indicated, a number of authors propose to consider freedom of conscience as a set of two concepts: "conscience" and "freedom". In this regard, freedom of conscience can be understood as a social necessity. The freedom of the individual, society as a whole is manifested not in the illusory independence from objective laws but in the ability to choose and make decisions. In theological concepts, true freedom is possible only within the religious worldview, and freedom of choice is correlated with freedom of religion, freedom of religion.

It is impossible to know the essence of the transcendent that this knowledge is irrational. Marxist religious studies solved this problem purely materialistically. However, a person's choice between the materialist and religious worldviews depends on the degree of awareness of the person, on the degree of knowledge of the laws of development (Beckwith, 2020). The higher the level of knowledge, the more confident the choice, the greater the degree of ignorance, the greater the temptation to compensate for it with either vulgar materialism, or declared atheism, or religious fanaticism.

The epistemological aspect of the study of the concept of freedom of conscience is directly related to ideological and socio-political grounds. It is these problems that have not received adequate social understanding and practical support for freedom of conscience (Odinochenko, 2016).

The formation of a person's attitude to the religious worldview is carried out under the influence of property, caste, moral, value, national ideas in the long process of selfknowledge and self-determination. In this process, it is difficult to interact with such factors as a person's perception of the world around him, depending on the person's objective laws and subjective characteristics, as well as the person's attitude to the world through the prism of religious or non-religious 
ideas. Considering the epistemological aspect of freedom of conscience (Oustinova-Stjepanovic, 2020), we can note the polar worldviews of the concept of freedom of conscience: religious and atheistic, which are opposite sides of a single set of problems related to the understanding of freedom of conscience. Political and legal prescriptions based on the absolutization of state and political interests, excessive politicization of the problems of freedom of conscience exacerbate the opposition of religious and atheistic worldview, lead to destructive interfaith contradictions and intrafaith divisions . Extrapolating this theoretical position to the social sphere, we consider the problem of the relationship between "person" and "society". In this regard, we can conclude that between believers and non-believers, between representatives of different religious systems, there is a worldview difference and confessional opposition and the possibility of interaction and cooperation. The area of such cooperation can be not only activities for the realization of universal values, solving problems of global importance, but also more private phenomena and processes, including domestic ones. Thus, it is possible to substantiate the principle of unity of all members of modern society, their equality regardless of religion. The history of the formation and development of ideas about freedom of conscience gives us a great deal of factual material about the relationship of these ideas with the worldview, political views, law and other aspects of public consciousness. In general, the analysis of the scientific literature can be seen underestimating the worldview of freedom of conscience, the absolutization of the role and importance of the legal aspect of

\section{References}

Ageshin, Ju. A. (1978). Politika i pravo. Ocherki teorii. Gosudarstvo, pravo, demokratija. Ocherkii teorii.

Ahdar, R. (2018). Is Freedom of Conscience Superior to Freedom of Religion? Oxford Journal of Law and Religion, 7(1), 124 142. https://doi.org/10.1093/ojlr/rwy006

Babie, P. (2013). Maclure Jocelyn and Taylor Charles (trans. Todd Jane Marie) Secularism and Freedom of Conscience Cambridge, Massachusetts and London, the concept, and underestimating the role and importance of the personal factor in the implementation of freedom of conscience. Analysis of freedom of conscience is often reduced to the selection of legal and moral aspects without taking into account the specifics of the concept of freedom of conscience, the relevance of its other aspects. Improving the guarantees of freedom of conscience is the key to the sustainable development of the state and global prosperity on the basis of equality and justice.

\section{CONCLUSIONS}

Thus, socio-legal studies of freedom of conscience cannot be imagined without considering it in various aspects, in their relationship, which in modern literature is often ignored. Based on a comprehensive social analysis of freedom of conscience, we can conclude that the most important aspects of freedom of conscience are social, philosophical and legal. Social and philosophical aspects are the theoretical basis for the analysis of freedom of conscience. The legal aspect allows taking into account the essence and specifics of the concept of freedom of conscience to analyze the existing legal guarantees of believers, nonbelievers and atheists, as well as prospects for further development of these guarantees. The effectiveness of this type of research allows us to more thoroughly consider the sociophilosophical and legal aspects as the most important in the theoretical analysis of freedom of conscience. However, the social study of freedom of conscience becomes "incomplete without taking into account the historical changes that this phenomenon has undergone in the course of its development.

England: Harvard University Press, 2011. 142 pp. Canadian Journal of Law and Society / Revue Canadienne Droit et Société, 28(02), 282-283. https://doi.org/10.1017/cls.2013.11

Babii, M.Yu. (1994). Svoboda sovisti: filosofske antropolobichne i relibioznavche osmyslennia. Vyshcha shkola.

Beckwith, F. J. (2020). Gotta Serve Somebody? Religious Liberty, Freedom of Conscience, and Religion as Comprehensive Doctrine. Studies in Christian Ethics, 33(2), 168- 
178. https://doi.org/10.1177/09539468198964 $\underline{18}$

Brazhnyk, I. I. (1999). Pravo. Relibiia. Ateizm: Pravoryi zmist nankovoho ateizmu. Naukova dumka.

Chavkin, W., Abu-Odeh, D., Clune-Taylor, C., Dubow, S., Ferber, M., \& Meyer, I. H. (2018). Balancing Freedom of Conscience and Equitable Access. American Journal of Public Health, 108(11), 14871488. https://doi.org/10.2105/AJPH.2018.304 $\underline{711}$

Donnikova, I., \& Kovban, A. (2020). Moral-legal self-regulation of freedom of conscience: Culturological aspect. Revista Amazonia Investiga, 9(32), 2835. https://doi.org/10.34069/AI/2020.32.08.3 Nauka.

Drobnickij, O. G. (1974). Ponjatie morali.

Elguédri, R., \& Ferjani, M. (2017). Religious Diversity and Freedom of Conscience in the Arabic Countries Facing Globalization and Migration. Religions, 8(10), 229. https://doi.org/10.3390/rel8100229

Farber, I. E. (1974). Svoboda i pravo cheloveka $v$ sovetskom gosudarstve. Izd-vo Saratovs'kogo unta.

Fleming, V., Ramsayer, B., \& Škodič Zakšek, T. (2018). Freedom of conscience in Europe? An analysis of three cases of midwives with conscientious objection to abortion. Journal of Medical Ethics, 44(2), 104108. https://doi.org/10.1136/medethics-2016$\underline{103529}$

Fylypovych, L. O. (2000). Legitimate guarantees of freedom of conscience. Ukrainian Religious Studies, 15, 9697. https://doi.org/10.32420/2000.15.1100

Kimelev, Ju. A., Poljakova N. D. (1998). Nauka i religija. Istoriko-kul'turnyj ocherk. Nauka.

Kolodnyi, A. M. (2005). Freedom of conscience in the formation of secular Ukraine.
Ukrainian Religious Studies, 36, 6480. https://doi.org/10.32420/2005.36.1623

Mariten, Zh. (2002). Chelovek i gosudarstvo. Ideja-pres.

Mykhaleyko, A. (2020). The New Independent Orthodox Church in Ukraine. Südosteuropa, 67(4), 476499. https://doi.org/10.1515/soeu-2019-0037

Novikov, M. A. (1980). Svoboda sovesti kak filosofs'ko-jeticheskaja kategorija.

Odinochenko, V. (2016). The right to freedom of conscience in modern Belarus: Problems of implementation. Religious Freedom, 1(19), 3639. https://doi.org/10.32420/rs.2016.19.1.916

Oustinova-Stjepanovic, G. (2020). End of organized atheism. The genealogy of the law on freedom of conscience and its conceptual effects in Russia. History and Anthropology, 31(5), 600-617. https://doi.org/10.1080/02757206.2019.16842 71

Pismanik, M. G. (1984). Individual'naja religioznost' i ee preodolenie.

Rozenbaum, Ju. A. (1985). Sovetskoe gosudarstvo i cerkov'.

Shahov, M. O. (2008). Religioznoe znachenie, ob\#ektivnoe znanie o religii i nauka. Voprosy filosofii, 11, 12-17.

Vélez, J. R. (2009). Freedom of Conscience in Ethical Decision Making. The Linacre Quarterly, 76(2), 120132. https://doi.org/10.1179/00243630980388 $\underline{9232}$

Werth, P. W. (Paul W. (2006). Toward \&quot;Freedom of Conscience\&quot;: Catholicism, Law, and the Contours of Religious Liberty in Late Imperial Russia. Kritika: Explorations in Russian and Eurasian History, 7(4), 843863. https://doi.org/10.1353/kri.2006.0061 